\title{
Analisis Pengaruh Harga dan Promosi Terhadap Tingkat Penjualan Pizza Hut di era Covid-19
}

\author{
Juliana $^{1}$, Amelda Pramezwary ${ }^{2}$ Catherine $^{3}$, Hermawan Dwitama ${ }^{4}$, Indah Sentia ${ }^{5}$ \\ 1,2,3,4,5 Fakultas Pariwisata, Universitas Pelita Harapan \\ E-mail : juliana.stpph@uph.edu (corresponding author)
}

\begin{abstract}
Cara Sitasi: Juliana, Amelda P, Catherine, Hermawan D, Indah S (2021) Analisis Pengaruh Harga dan Promosi Terhadap Tingkat Penjualan Pizza Hut di era Covid-19, 2021 21(2), 74 - 78 Retrieved from https://doi.org/10.31294/jc.v19i2
\end{abstract}

\begin{abstract}
This study aims to analyze the effect of price and promotion on the sales level of Pizza Hut in the Covid19 era. This research is a basic research to fill the research gap in sales level studies. two hypotheses and tested using data collected from 150 respondents of pizza hut customers. This research is driven by the Covid-19 pandemic which has brought a downturn for companies in marketing products produced by these companies, especially companies in the field of food and beverage. Researchers use quantitative research with multiple linear regression analysis techniques to analyze how much influence the independent variables interact with. dependent variable. Researchers found that the variable that had the most significant influence on Pizza Hut sales in the Covid-19 era was promotion. The decline in Pizza Hut prices did have an effect on the increase in Pizza Hut sales but the effect was not too significant. This is due to the intense price competition to attract consumers' attention in this pandemic. Thus, it is evident that the Pizza Hut promotion strategy by attracting public sympathy can increase sales in the Covid-19 era.
\end{abstract}

Keywords: price, promotion, sales level, covid-19

\section{PENDAHULUAN}

Dunia saat ini sedang dilanda oleh suatu pandemi yang belum pernah dirasakan dalam skala sebesar ini yaitu coronavirus (Covid-19). Virus yang ditemukan di kota Wuhan, China ini kemudian menginfeksi banyak orang dan menyebar ke negara di seluruh dunia akibat perjalanan orang yang terinfeksi namun masih dalam masa inkubasi (incubation period).

World Health Organization yaitu agensi spesialisasi bawahan United Nations menyatakan bahwa COVID-19 dapat digolongkan sebagai pandemi global karena Covid-19 dapat menyebar dengan cepat dan dapat dikatakan tidak terkendali. Centers for Disease Control and Prevention (CDC), mengungkapkan bahwa pandemi dapat diberikan nama tersebut jika penyebaran virus dapat terjadi dengan cepat dan berlanjut ke wilayah-wilayah lain dengan mudah.

Dalam upaya menghadang penyebaran Covid-19, WHO memberikan banyak arahan seperti menerapkan kebijakan physical distancing, yang dilakukan oleh semua organisasi baik dari sekolah sampai perusahaan-perusahaan di mana orang bekerja, oleh sebab itu muncul kebijakan bekerja dari rumah atau "work from home". (WHO, 2020)

Hubungan antar masyarakat pun berubah secara drastis. Hubungan yang dibangun sebuah Perusahaan dengan masyarakat di sekitarnya juga ikut mengalami perubahan yang signifikan. Social distancing, isolasi mandiri dan pengurangan perjalanan telah menyebabkan berkurangnya tenaga kerja di semua sektor ekonomi dan menyebabkan banyak orang hilang pekerjaan. Sekolah telah ditutup, dan kebutuhan akan komoditas dan produk manufaktur telah menurun.

Perekonomian global akan membutuhkan waktu yang lama untuk pulih. Banyak perusahaan mengalami penurunan permintaan, bahkan beberapa dari mereka mungkin menghadapi tantangan pasokan, dan terancam akan gulung tikar. Pemerintah mengimbau untuk melakukan pembatasan sosial dan juga isolasi mandiri untuk mengurangi penyebaran virus. Namun, pembatasan sosial dan juga isolasi mandiri ini menyebabkan melambatnya bisnis-bisnis , terutama bisnis yang membutuhkan adanya manusia yang melakukan interaksi dengan masyarakat secara langsung pada umumnya seperti retail, pariwisata, dan juga MICE. Hal ini dikarenakan kebijakan pemerintah dalam menurunkan penyebaran virus yang menurunkan minat pengunjung dan pembeli.

Semua sektor perekonomian mengalami masalah yang sama. Terutama dalam bisnis $F \& B$ yang biasa menyiapkan makanannya di tempat secara langsung. Penurunan keinginan masyarakat dalam mengkonsumsi makanan di tempat secara langsung membuat peluang bagi bisnis baru seperti layanan pengantaran makanan muncul dan telah meningkat secara signifikan karena semakin banyak orang yang menerapkan anjuran pemerintah untuk stay at home. Masa pandemi Covid-19 adalah masa yang sangat menantang bagi semua bisnis, termasuk bisnis food and beverage yang merupakan kebutuhan berbagai golongan masyarakat. (Prakoso, 2020)

Berdasarkan data yang dilansir oleh Bank Indonesia, tercatat bahwa dalam hasil survei kegiatan usaha pada triwulan I tahun 2020, terjadi penurunan dibandingkan triwulan sebelumnya secara signifikan yang diduga besar disebabkan oleh penyebaran virus 
corona. Dalam industri food and beverage, kebijakan social distancing yang diterapkan oleh pemerintah selama masa pandemi Covid-19 berdampak langsung terhadap omzet pendapatan restoran yang turun terjun hingga 70 sampai $80 \%$. Ratusan perusahaan tidak bisa menghindari mengambil jalan terakhir yaitu pemutusan hubungan kerja akibat resesi ekonomi yang melandanya. Berdasarkan data yang dilansir dari database (2020), bisnis startup sektor makanan dan minuman yang terkena dampak korona berada pada poin 3.1 dari 4

Berdasarkan data yang diperoleh dari lokadata, persentase WNI yang makan langsung (dine-in) di restoran pada periode pandemi Covid-19 terdapat $9 \%$, takeaway dari restoran sebesar $22 \%$, aplikasi $23 \%$, memasak di rumah dengan keluarga sebesar $44 \%$, dan masak untuk kebutuhan sendiri sebesar $67 \%$. Dari data tersebut, dapat disimpulkan bahwa penyebab utama startup makanan dan minuman mengalami penurunan pendapatan dikarenakan mayoritas masyarakat saat pandemi lebih memilih untuk memasak sendiri. Dampak pandemi Covid-19 memang sudah sangat terasa bagi dunia usaha, namun di sisi lain pandemi ini menantang keahlian marketing dan manajemen strategis yang menjadi elemen penting dan ketika krisis seperti ini melanda. Kebutuhan dan tuntutan pekerjaan bagi para profesional di bidang marketing dan manajemen strategis di semua bidang bisnis dan di semua lini pembangunan saat ini mencapai angka tertinggi di tahun-tahun terakhir. Dalam krisis global saat ini, semua institusi perlu berusaha untuk semakin relevan dan adaptif dalam menanggapi Covid-19. Mereka perlu senantiasa menjaga ekosistem bisnis mereka dan memastikan bahwa hubungan dengan para stakeholder berjalan dengan baik dan memiliki tujuan utama memulihkan perekonomian selama pandemi.

Apabila strategi perusahaan kurang tepat maka perusahaan tersebut tidak dapat bertahan karena selama pandemi ini, kompetitor akan terus muncul dan juga senantiasa meningkatkan kreativitas mereka dalam menjual produk mereka, belum ditambah dengan permintaan yang masih menurun. Hal ini sangat terasa bagi semua perusahaan yang bergerak di bidang food and beverage yang mencari profit di pandemi Covid-19 dan hal ini tentunya tidak mengecualikan Pizza Hut. Meskipun Pizza Hut merupakan perusahaan yang sudah berdiri sejak tahun 1958, dampak dari pandemi Covid-19 ini tidak dapat dihindari. Pizza Hut membutuhkan sebuah strategi pemasaran yang tepat untuk dapat bertahan di masa pandemi ini.

Semua perusahaan saat ini bersaing secara ekstrim untuk memenangkan hati konsumen. Perusahaan-perusahaan berpikir keras dalam menyusun berbagai strategi pemasaran yang berfokus terhadap penjualan dan keputusan beli konsumen. Usaha mempertahankan kelangsungan hidup perusahaan dengan pemasaran merupakan upaya yang sangat penting. Pemasaran difokuskan untuk meningkatkan penjualan perusahaan yang menurun secara drastis saat pandemi ini. Dalam pemasaran, perusahaan memikirkan cara sehingga terjadi penjualan yang memenuhi kriteria tertentu dari perusahaan itu sendiri.(Donthu \& Gustafsson, 2020)

Perusahaan harus mampu menghubah mereka memasarkan sesuatu dengan cara mengembangkan strategi promosi agar penjualan dapat meningkat. Promosi merupakan strategi yang dapat diimplementasikan untuk meningkatkan atau secara paling minimal mencoba untuk mempertahan volume perjualan yang sudah ada. Perubahan kebiasaan pasar harus dijadikan sebuah tantangan bagi perusahaan untuk mengeluarkan berbagai strateginya yang dapat diarahkan ke target market secara spesifik. Meskipun promosi sangat dibutuhkan untuk meningkatkan penjualan, perusahaan juga perlu menekan biaya promosi untuk meningkatkan pendapatan bersih penjualan. (Kotler, 2012)

Menurut (Baker, 2016) Promotional mix adalah gabungan dari berbagai tools promosi yang dapat berupa iklan, penjualan secara langsung promosi dan juga publisitas yang dibuat untuk menjual. Promosi yang sebagaimana didefinisikan oleh (Kotler, 2012) adalah segala aktivitas pemasaran yang ditujukan untuk menyebarkan informasi target pasar sehingga mereka terpengaruh dan juga untuk menstimulasi keinginan mereka untuk melakukan suatu transaksi.

Pizza Hut merupakan restoran yang identik dengan kelas menengah sampai menengah ke atas sebelum krisis. Selama pandemi, Pizza Hut berusaha untuk melakukan cara promosi lain. Dalam pandemi ini, seperti bisnis lainnya, Pizza Hut harus berpikir secara kreatif dan berinovasi agar dapat bertahan dalam keterpurukan ini. Aksi Pizza Hut turun ke jalan pun kemudian mendapatkan simpati dari netizen di dunia maya. Di tengah krisis pandemi yang Covid-19, kini Pizza Hut membuat suatu strategi pemasaran agar dapat bertahan. Pizza hut mempromosikan bahwa dengan Rp 100 ribu, konsumen bisa mendapatkan 4 pizza yang berukuran personal. Dapat dilihat bahwa Pizza Hut menggunakan strategi harga dan promosi untuk meningkatan penjulan produk

Pentingnya aktivitas pemasaran serta oleh Pizza Hut dalam menarik konsumen untuk melakukan transaksi untuk meningkatkan performa penjualan perusahaan, dan dari alasan berikut penulis akan melakukan penelitian yang bertujuan untuk menganalisis harga dan promosi sebagai independent berpengaruh terhadap tingkat penjualan sebagai variabel yang terikat. Rumusan masalah dalam penelitian ini apakah terdapat pengaruh harga dan promosi terhadap tingkat penjualan Pizza Hut di era Covid-19?.

Harga dapat diartikan sebagai nilai dari suatu produk atau jasa untuk mendapatkan manfaat memiliki dan menggunakan. Menurut Gitosudarmo (Gitosudarmo, 2014), harga adalah suatu ukuran yang menentukan besar kecilnya kepuasan konsumen terhadap produk 
yang dibelinya. Dharmmesta (Swastha, Basu Dharmmesta, 2014) menjelaskan bahwa harga dipengaruhi oleh berbagai faktor seperti internal dan eksternal. Dalam situasi seperi ini, harga produk dipengaruhi oleh pandemi Covid-19 sebagai faktor lingkungan eksternal.

Promosi menurut (Kotler, 2012) adalah proses komunikasi antara penjual dengan pembeli yang ditujukan untuk menstimulasi demand terhadap produk yang dijual. Promosi merupakan usaha yang dibuat untuk menstimulasi demand tanpa mengubah product mix, price, dan juga sistem distribusi. Promotion adalah kombinasi dari iklan, promosi penjualan, personal selling atau sales, dan juga publicity. Penjualan menurut (Nafarin, 2013) merupakan suatu tahapan dari kegiatan menjual yang terdiri dari kegiatan penetapan harga jual sampai distribusi produk sampai kepada konsumen. Serupa dengan (Kotler, 2012) yang menyatakan bahwa penjualan merupakan proses sosial manajerial dimana individu dan kelompok mendapatkan apa yang dibutuhkan dan inginkan, menciptakan, menawarkan, dan mempertukarkan produk yang bernilai dengan pihak lain.

\section{Rerangka Pemikiran}

Berikut merupakan rerangka pemikiran dalam penelitian ini:

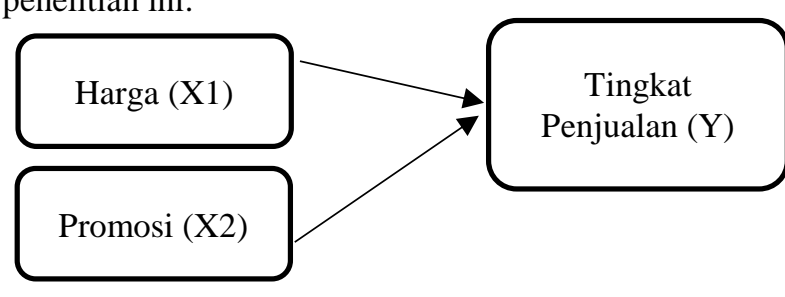

Sumber : dikembangkan dalam penelitian ini (2021)

\section{Gambar 1. Rerangka Pemikiran}

Oleh karena penjelasan diatas maka dibuat hipotesis sebagai berikut :

H1: Harga berpengaruh signifikan terhadap tingkat penjualan Pizza Hut di era Covid-19

$\mathrm{H} 2$ : Promosi berpengaruh signifikan terhadap tingkat penjualan Pizza Hut di era Covid-19

\section{METODOLOGI PENELITIAN}

Populasi dalam penelitian ini merujuk pada konsumen Pizza Hut di Jakarta Pusat. Sampel adalah bagian kecil dari suatu populasi. Peneliti menggunakan data primer dengan teknik non random sampling, yaitu teknik pemilihan sampel yang sama tidak memungkinkan terjadinya kesamaan peluang terhadap setiap populasi yang dipilih sebagai sampel. Sampel yang didapatkan sebanyak 150 responden. Data tersebut dikumpulkan untuk menjawab permasalahan yang sudah peneliti rumuskan. Oleh karena itu peneliti menggunakan teknik pengumpulan data non probability sampling di mana peneliti tidak memberikan peluang bagi anggota populasi untuk dipilih.(Sekaran \& Bougie, 2016) Sampel yang dipilih oleh peneliti memiliki karakteristik tertentu yang telah ditentukan sebelumnya, peneliti memilih pelanggan yang melakukan pembelian di Pizza Hut selama pandemi Covid-19 sebanyak dua kali.

Dalam penelitian ini peneliti menggunakan 2 jenis data, yakni data primer dan data sekunder. Menurut data primer merupakan data yang terkumpul secara langsung dari sumber atau tempat penelitian oleh peneliti. Data tersebut diperoleh melalui berbagai cara seperti kuisioner maupun hasil wawancara sendiri. Setelah terkumpul, data tersebut harus diolah. Kuesioner digunakan karena dapat diberikan secara langsung dari peneliti kepada responden, selain itu juga dapat diberikan via online. Kuesioner merupakan lembar yang berisi pertanyaan yang diberikan masukan oleh para responden. Skala pengukuran analisis ini menggunakan skala likert. Skala likert ini dapat digunakan yang bertujuan untuk mengetahui tingkat setuju dan tidak setujunya responden (Sekaran \& Bougie, 2016) Jawaban dari setiap item yang ada dalam menggunakan skala likert ini mempunyai hasil dari yang positif sekali hingga negatif, Penelitian ini juga menggunakan studi kepustakaan dengan cara mengkaji beberapa literatur dan referensi lain yang memiliki hubungan dengan penelitian. Studi pustaka dapat dilakukan dengan mengamati dan menyimpulkan berbagai data dari literatur dan juga sumber lainnya yang berkaitan sehingga memberikan informasi yang diperlukan oleh peneliti untuk menyelesaikan penelitian. Studi kepustakaan dilakukan oleh peneliti untuk mencari data sekunder. Penelitian ini menggunakan deskriptif kuantitatif dengan analisis data menggunakan analisis deskriptif dan dengan pendekatan partial least square- structural equation modelling (PLS -SEM). (Hair et al., 2014). Model pengukuran (outer model) pada penelitian ini digunakan untuk menguji validitas konstruk dan reliabilitas instrument. Convergent validity dari model pengukuran dianggap valid jika mempunyai nilai AVE > 0.5 dan factor loading $>0.70$. Pada uji reliabilitas, suatu indicator dianggap reliabel jika mempunyai Cronbach's alpha 0.7 dan nilai composite reliability $>0.7$ (Gozali \& Latan, 2015). Pengujian hipotesis dilaksanakan dengan menggunakan analisis Partial Least Square (PLS) dengan menggunakan program Smart PLS 3.0

\section{HASIL DAN PEMBAHASAN}

Subjek dari penelitian ini adalah konsumen yang membeli Pizza Hut sebanyak dua kali selama pandemic Covid-19 ini berlangsung. Dari 150 form yang peneliti sebarkan sebanyak 87 responden merupakan laki-laki dan 63 responden merupakan perempuan. Responden tersebut memiliki rentang usia sebagai berikut : 51 responden berusia antara 20-25 tahun 45 responden berusia antara 26-30 tahun 30 responden berusia antara 31-35 tahun 15 responden berusia antara 36-40 tahun dan 9 responden berusia diatas 40 tahun. Hasil pengolahan data pada tabel 1 
menghasilkan pengukuran instrumen dinyatakan valid.

Tabel 1. Evaluasi Model Pengukuran

\begin{tabular}{|l|l|}
\hline $\begin{array}{l}\text { Konstruk dan } \\
\text { Item }\end{array}$ & Outer Loading \\
\hline $\begin{array}{l}\text { Harga (AVE= } \\
\text { 0.640, CR= } \\
0.775)\end{array}$ & \\
\hline PR1 & 0.877 \\
\hline PR2 & 0.884 \\
\hline PR3 & 0.723 \\
\hline PR4 & 0.835 \\
\hline PR5 & 0.750 \\
\hline $\begin{array}{l}\text { Promosi } \\
\text { AVE= 0.738 }\end{array}$ & \\
CR=0.897) & \\
\hline PROM1 & 0.858 \\
\hline PROM2 & 0.853 \\
\hline PROM3 & 0.889 \\
\hline PROM4 & 0.745 \\
\hline PROM5 & 0.792 \\
\hline Tingkat & \\
Penjualan & \\
(AVE= 0.661 & \\
CR=0.803) & \\
\hline TP1 & 0.772 \\
\hline TP2 & 0.855 \\
\hline TP3 & 0.703 \\
\hline TP4 & 0.732 \\
\hline TP5 & 0.815 \\
\hline Not: AVE Avera Vanace of \\
\hline
\end{tabular}

Note : AVE Average Variance of

Extracted. $\mathrm{CR}=$ composite reliability, *significant (one-tailed test, $\mathrm{p}<0.05)$

Sumber : Hasil Olah Data PLS (2021)

Kemudian Tabel 2 mengungkapkan bahwa uji discriminant validity telah terpenuhi yakni nilai akar AVE lebih besar dari nilai korelasi antar variabel

Tabel 2. Kriteria Fornel-Larcker

\begin{tabular}{|c|c|c|c|}
\hline & Harga & Promosi & $\begin{array}{c}\text { Tingkat } \\
\text { Penjualan }\end{array}$ \\
\hline Harga & 0.813 & & \\
\hline Promosi & 0.715 & 0.779 & \\
\hline $\begin{array}{c}\text { Tingkat } \\
\text { Penjualan }\end{array}$ & 0.810 & 0.759 & 0.821 \\
\hline
\end{tabular}

Sumber : Hasil Olah Data PLS (2021)

Dalam tahap model struktural menghitung $\mathrm{R}^{2}$ serta uji collinearity dan uji hipotesis. Semakin besar nilai $\mathrm{R}^{2}$ maka semakin baik prediksi konstruk eksogen terhadap konstruk endogen. Dalam hal ini dijelaskan bahwa konstruk tingkat penjualan memiliki $\mathrm{R}^{2}$ sebesar $49 \%$ sisanya sebesar $51 \%$ dijelaskan oleh konstruk lainnya yang tidak dimasukkan dalam model penelitian. Pengujian selanjutnya adalah uji collinearity untuk mengetahui apakah model memiliki kecenderungan collinearity. Batas nilai VIF untuk mengetahui apakah terdapat kecenderungan collinearity adalah maksimal 5.0. Jika Jika nilai VIF lebih dari 5.0 maka ada kecenderungan collinearity (Hair et al., 2014). Tabel 3 menunjukkan bahwa nilai VIF pada model dibawah 5.0. maka dapat disimpulkan bahwa tidak terdapat collinearity pada model.

Tabel 3. Evaluasi Collinearity

\begin{tabular}{|l|l|}
\hline Sebagai Prediktor Tingkat Penjualan \\
\hline Konstruk & VIF \\
\hline Harga & 1.008 \\
\hline Promosi & 1.044 \\
\hline
\end{tabular}

Sumber : Hasil Olah Data PLS (2021)

Kemudian dilanjutkan dengan pengujian hipotesis dilaksanakan untuk menganalisis seberapa besarnya pengaruh antar konstruk diterima atau tidak diterima. Pengujian hipotesis memperhatikan batas ttabel yakni sebesar 1.65 (level of signifikansi=5\%). Pada tabel 4 disimpulkan bahwa hipotesis signifikan dan ada satu hipotesis yang tidak signifikan.

Tabel 4. Hasil Uji Hipotesis

\begin{tabular}{|c|l|c|c|}
\hline Hipotesis & $\begin{array}{c}\text { Standardize } \\
\text { d path } \\
\text { coefficient }\end{array}$ & $\begin{array}{c}P \\
\text { Value } \\
s\end{array}$ & $\begin{array}{c}\text { Keputusa } \\
\mathrm{n}\end{array}$ \\
\hline $\begin{array}{c}\text { Harga } \\
\text { berpengaru } \\
\text { h signifikan } \\
\text { terhadap } \\
\text { tingkat } \\
\text { penjualan }\end{array}$ & $\begin{array}{l}\text { Harga } \longrightarrow \\
\text { Tingkat } \\
\text { Penjualan }\end{array}$ & 0.419 & $\begin{array}{c}\text { Tidak } \\
\text { Diterima } \\
\text { atau } \\
\text { Ditolak }\end{array}$ \\
$\begin{array}{c}\text { Promosi } \\
\text { berpengaru } \\
\text { h signifikan } \\
\text { terhadap } \\
\text { tingkat } \\
\text { penjualan }\end{array}$ & $\begin{array}{c}\text { Promosi } \\
\text { Tingkat }\end{array}$ & 0.000 & $\begin{array}{c}\text { Didukung } \\
\text { atau } \\
\text { diterima }\end{array}$ \\
& & & \\
\hline
\end{tabular}

Sumber : Hasil Olah Data PLS (2021)

Hasil pengujian hipotesis harga tidak berpengaruh signifikan terhadap tingkat penjualan sedangkan promosi berpengaruh signifikan terhadap tingkat penjualan. Hal ini dikarenakan saat pandemic Covid-19 ini, berbagai usaha di bidang makanan dan miinuman berlomba-lomba untuk menurunkan harga dengan tujuan menarik perhatian konsumen dan meningkatkan penjualan. Penurunan harga yang terjadi dimana-mana ini mengakibatkan banyaknya pilihan atau alternatif lain kepada konsumen dalam memilih makanan yang akan dikonsumsinya. Semakin banyaknya pilihan, akan menurunkan probabilitas terpilihnya Pizza Hut sebagai makanan yang dikonsumsi masyarakat di era Covid-19 ini.

Selain harga, ada variable lainnya yang tidak kalah penting untuk menarik perhatian konsumen, yaitu promosi. Strategi promosi Pizza Hut sangat berpengaruh signifikan terhadap tingkat penjualan. Hal ini dikarenakan oleh simpati masyarakat akan Pizza Hut yang turun ke jalan untuk berjualan produknya.

\section{PENUTUP}


Hasil dari pengujian hipotesis penelitian menyatakan bahwa harga tidak berpengaruh signifikan terhadap tingkat penjualan dan promosi berpengaruh signifikan terhadap tingkat penjualan. Dengan demikian Pizza Hut harus memfokuskan strateginya dalam promosi untuk meningkatkan penjualan pada masa pandemic covid 19 ini.

Berdasarkan simpulan dari apa yang terpapar diatas, dapat disimpulkan bahwa para peneliti selanjutnya dapat menambahkan beberapa variable lainnya yang lebih beragam dan lebih mendalam untuk melanjutkan penelitian ini seperti menambahkan variabel mediasi ataupun moderasi maupun variabel lainnya seperti brand image, brand loyalty serta hasil penelitian ini juga dapat terus di perluas dan juga responden akan terus bertambah menjadi lebih banyak lagi, sehingga hasil-hasil selanjutnya dapat mendapatkan hasil yang lebih tajam dan lebih merinci lagi dari sebelumnya. Serta hasil penelitian ini dapat sedikit membantu para peneliti selanjutnya jika penelitian yang akan dilakukan adalah penelitian serupa.

\section{DAFTAR PUSTAKA}

Baker, M. J. (2016). The marketing mix. In The Marketing Book: Seventh Edition. https://doi.org/10.4324/9781315890005

Donthu, N., \& Gustafsson, A. (2020). Effects of COVID-19 on business and research. In Journal of Business Research. https://doi.org/10.1016/j.jbusres.2020.06.008

Gitosudarmo, I. (2014). Manajemen pemasaran. Yogyakarta: BPFE-Yogyakarta.

Gozali, I., \& Latan, H. (2015). Patrial Least Squeres Konsep, Teknik, dan Aplikasi Menggunakan Program SmartPLS3.0. In Semarang: UNDIP. https://doi.org/10.9744/jmk.21.1.1-8

Hair, Joseph F., Black, W.C, Babin, B.J \& Anderson , R, E. (2014). Multivariate Data Analysis Pearson Education Limited. Harlow. England (7th Editio). Pearson Education Limited. Harlow. England.

Hair, J. F., Sarstedt, M., Hopkins, L., \& Kuppelwieser, V. G. (2014). Partial least squares structural equation modeling (PLS-SEM): An emerging tool in business research. In European Business Review. https://doi.org/10.1108/EBR-10-20130128

Kotler, P. (2012). Marketing management/Philip Kotler, Kevin Lane Keller. Pearson Education International.

Nafarin, M. (2013). Penganggaran Perusahaan. In Jakarta: Salemba Empat.

Prakoso, fajar A. (2020). Dampak Coronavirus Disease (Covid-19) Terhadap Industri Food \& Beverages. Manajemen Bisnis.

Sekaran, U., \& Bougie, R. J. (2016). Research Methods For Business. Wiley. https://search.ebscohost.com/login.aspx?direct $=$ true $\&$ scope $=$ site $\& \mathrm{db}=$ nlebk $\& \mathrm{db}=$ nlabk $\& \mathrm{AN}=$ 1639487

Swastha, Basu Dharmmesta, T. handoko. (2014). Manajemen Pemasaran. In PBFE Yogyakarta.

WHO. (2020). Coronavirus disease (COVID-19) advice for the public. Coronavirus disease 2019.

\section{PROFIL PENULIS}

Juliana adalah dosen Fakultas Pariwisata Universitas Pelita Harapan

Amelda Pramezwary adalah Ketua Program Studi Pengelolaan Perhotelan Fakultas Pariwisata Universitas Pelita Harapan

Catherine adalah mahasiswa Program Studi Pengelolaan Perhotelan Fakultas Pariwisata Universitas Pelita Harapan

Hermawan Dwitama adalah mahasiswa Program Studi Pengelolaan Perhotelan Fakultas Pariwisata Universitas Pelita Harapan

Indah Sentia adalah mahasiswa Program Studi Pengelolaan Perhotelan Fakultas Pariwisata Universitas Pelita Harapan 